\title{
Lyrical I in Poetic Discourse of Carl Sandburg: A Linguo-Cognitive Approach
}

\author{
Vira Babych ${ }^{1} \&$ Iryna Nedainova ${ }^{2}$ \\ ${ }^{1}$ Pylyp Orlyk International Classical University, Mykolaiv, Ukraine \\ ${ }^{2}$ National Technical University “Kharkiv Polytechnic Institute”, Kharkiv, Ukraine \\ Correspondence: Vira Babych, Pylyp Orlyk International Classical University, Mykolaiv, Ukraine. E-mail: \\ pylyporlykuniversity@gmail.com
}

\author{
Received: February 8, 2020 Accepted: March 10, 2020 Online Published: March 18, 2020 \\ doi:10.5539/ijel.v10n3p133 URL: https://doi.org/10.5539/ijel.v10n3p133
}

\begin{abstract}
The article deals with the linguo-cognitive analysis of the expression of the lyrical I in the poetic discourse of the prominent representative of the epoch of American modernism - Carl Sandburg.

The lyrical I is understood as a poet's imagery in which the image of a lyrical hero and the image of the author are united in a syncretic way and which represents a three-fold linguo-cognitive construct that incorporates a conceptual, pragmatic and verbal embodiments.

Based on the analysis made in the research, the authors arrived at the conclusion that Carl Sandburg's lyrical I describes a man of labor, depicts a difficult life of a man in an industrial city, shows the author's appeal in support of a man's fighting for his rights, for peace and freedom. In the poetic discourse of Carl Sandburg, the lyrical $I$ is represented with the help of an urban figurativeness, a newspaper style of the language, a perfect skill of use of a blank verse resembling a song folklore, and a wide use of local expressions and dialectal words, colloquial language and prosaisms.
\end{abstract}

Keywords: lyrical I, poetic discourse, poetry of Carl Sandburg, linguo-cognitive analysis, epoch of American modernism

\section{Introduction}

There is no doubt that a poetic discourse differs greatly from any other types of discourses including fiction (prose). The main differences lie in the fact that the key features of a poetic discourse are revealed in the author's subjectivity and self-expression, in constructing his own individual reality, in using a great many of evaluative and emotive lexis that helps to create vivid visual and acoustic images, in referring to the philosophy of estrangement that advocates alienation of a man from the social world and his loneliness, his readiness to accept the absurdity of his existence and to dive into his own feelings and emotions. A poetic discourse is characterized by a high degree of syncretism, metaphoricity and universalism. It often describes as a discourse of chaos, lack of definite criteria of values and meaningful orientation of a man in the world, as a discourse of vagueness, incompleteness and uncertainty (Gavins \& Steen, 2003; Stockwell, 2007; Aubakir, 2019, etc.).

As the famous French scholar Emile Benveniste stated, the status of poetic discourse is a complex problem of modern linguistics that has to be solved in terms of revision of the basic categories of linguistic analysis (Benveniste, 1980). It deals with a critical analysis of such notions as communication, reference, utterance, message, sign, etc. and their projection to the discourse of poetry in the specificity of its anthropocentric character.

In this context, one of the main categories of a poetic discourse that requires a thorough investigation is the lyrical $I$ which we understand as a poet's imagery in which the image of a lyrical hero and the image of the author are synthetically united. A lyrical hero can be represented by living creatures (people, animals, etc.) and inanimate ones (plants, cities, villages, etc.), different phenomena of nature (rain, snow, wind, season, etc.) and even abstract notions (love, life, death, etc.). We assume that lyrical I represents a three-fold linguo-cognitive construct that incorporates a conceptual, pragmatic and verbal embodiments. The conceptual image expresses the general content of the lyrical $I$ which is structured by conceptual schemas that reflect the author's artistic consciousness. The pragmatic expression realizes the sender's intentions reflected in his communicative and 
pragmatic strategies which in their turn are implemented by means of various stylistic devices. The verbal image is reflected in the explicit expressions of the lyrical $I$ and its implicit meanings at the lexico-semantic and syntactical levels of a poetic text.

\section{Literature Review}

Poetic discourse has always attracted attention of linguists all over the world. Among the works dealing with the analysis of the nature of a poetic discourse and its linguistic peculiarities, it is worth mentioning those by Van Dijk (1979), Hoffstaedter (1987), Tsur (1992), Hanauer (1997), Dixon, Bortolussi, Twilley and Leung (1993), Tillmann and Dowling (2007), Stockwell (2007), Koepsell and Spoerhase (2008), Walsh (2010) and others.

The role of emotions as a characteristic feature of a poetic discourse has also been in the scope of scientific interest of many linguists: Kneepkens and Zwaan (1994), Barrett, Lindquist and Gendron (2007), Briesemeister, Kuchinke, Jacobs and Braun (2014), Ullrich, Aryani, Kraxenberger, Jacobs and Conrad (2015), etc.

"Evocation of social situations and the associated empathic reactions of the perceiver represent a chill-driving factor that is exploited by poetic language. Poetry has a particularly pronounced focus on highly self-relevant and intimate forms of emotional and social attachment. It therefore typically dwells on personal dilemmas, romantic love and deep friendship. Importantly, the feelings of close personal attachment are usually unfulfilled in poems in one form or another, as in cases of unrequited love, sacrifice of love due to unfortunate circumstances, or a friendship that is put to a hard test. All of this adds gravity and seriousness to these highly self-relevant and intrinsically pleasant issues, thereby triggering concomitant feelings and expressions of negative affect. This blend ultimately leads to states of being emotionally moved." (Wassiliwizky, Koelsch, Wagner, Jacobsen, \& Menninghaus, 2017).

Lately there appeared researches that deal with the analysis of a poetic discourse that implement a linguo-cognitive approach in them.

Marina, for instance, studies the paradoxicality in modern English poetic discourse emphasizing the formation of paradoxical poetic forms as a result of linguistic and cognitive activity of the addresser and the addressee ensured by linguistic and cognitive processes of precategorization, acategorization and categorization (Marina, 2018).

Ángel Luján Atienza focuses on the elements for a cognitive analysis of poetic discourse stating that they can be structured according to the three levels of discourse analysis: the sentence level to which the principles of cognitive grammar are applied; the textual level, where the viability of the theory of textual worlds in poetry is shown; and the discursive level, where the problems of the poetic subject and the generic identity of poetry are reconsidered from a cognitive perspective (Luján Atienza, 2019).

Still, the poetic heritage of the great American poet of the 20th century Carl Sandburg has not been analyzed in terms of use of the linguo-cognitive approach yet.

\section{Materials and Methods}

The article deals with the analysis of the peculiarities of the expression of lyrical I in the poetic discourse of one of the outstanding representatives of the epoch of American modernism-Carl Sandburg. Thus, the poems written by Carl Sandburg serve the material of our research (Sandburg, 2012). The following methods were employed during our research: methods of lexical and semantic, syntactical and stylistic analysis of a poetic text that enable the study of linguostylistic peculiarities of the poetic discourse of Carl Sandburg, methods of cognitive, semantic and conceptual analysis of a poetic text aimed at revealing the author's unique concepts with the help of which his lyrical I is reconstructed in poetry.

\section{Discussion and Results}

Lyrical I, as we can see it, reflects an author's subjective concept of the world and his self-expression in a poetic text revealing a poet's individual reality characterized by a communicative and pragmatic influence on the reader (the addressee) which is realized with the help of the usage of certain linguo-cognitive, communicative and pragmatic mechanisms.

In relation to its content, lyrical I represents a poet's linguistic personality as a subject of a social life including his personal qualities, philosophical views, historical experience, system of knowledge, etc. In this context, a poet's linguistic personality is able to artistically reflect the realia of the objective world on the basis of its creative perception, esthetic motivation, creative thinking, imagination, fantasy, and speech and mental activity taking into account the specificity of a poetic text organization.

A famous Russian poet Vladimir Mayakovsky once called Carl Sandburg "the great industrial poet of America" 
defining most accurately the essence of his creative work. The scholars who analyzed the literary heritage of Carl Sandburg (Jones, 1980. Mark \& Neely, 1983; Callahan, 1987; Salwak, 1988; Philip, 1996; Reed, 2004; Villarreal, 2006; Spacey, 2019; and others) emphasize that the main motifs of Carl Sandburg's poetry are a filial love for the prairie, a poetic praise of a modern city, sometimes accompanied by hatred towards it, a revaluation of a great number of cultural and social values and their critical estimation, features of fatigue during the skeptical development of the themes of frailness and fatalism together with optimistic penetrations into the utopian tomorrow.

One of the main sources of Carl Sanburg's poetic inspiration is the huge industrial city of America of capitalist era. The author often hides its contradictions praising the power of its creation, the live and boiling joy of life, of being rude, powerful and creative.

I tell them where the wind comes from,

Where the music goes when the fiddle is in the box.

Kids - I saw one with a proud chin, a sleepyhead,

And the moonline creeping white on her pillow.

I have seen their heads in the starlight

And their proud chins marching in a mist of stars.

They are the only people I never lie to.

I give them honest answers,

Answers shrewd as the circles of white on brown chestnuts.

(C. Sandburg, "People with Proud Chins")

Sandburg's poetry is characterized by an urban figurativeness, a newspaper style of language, a high mastery of blank verse close to song folklore. Thus, urban landscapes, contrasts and dramas of the everyday life of a huge city reflected with the reportage accuracy, the prairie, the natural life of people resisting modern civilization are the main motifs in the poetic discourse of Carl Sandburg.

There can easily be seen the influence of W. Whitman on the favorite form of a blank verse often used by Carl Sandburg and handle by him with an exceptional flexibility and expressivity.

I painted on the roof of a skyscraper.

I painted a long while and called it a day's work.

The people on the corner swarmed and the traffic cop's whistle never let up all afternoon.

They were the same as bugs, many bugs on their way-

These people on the go or at a standstill;

And the traffic cop a spot of blue, a splinter of brass,

Where the black tids ran around him

And he kept the street. I painted a long while

And called it a day's work.

(C. Sandburg, "People Who Must")

As a regional poet of the Middle West, Carl Sandburg widely uses local expressions and dialectal words, simple language and prosaisms. Such instruments helped him to gain a reputation of a "difficult-to-understand" author whose poems can hardly be adequately translated into other languages. Sandburg's language may often seem rough and clumsy.

It is hard not to see that Carl Sandburg's poetry is filled with the echoes of collisions, dramas, hopes and disappointments aroused by a rapid development of industry which resolutely reconstructed the style of the American life. Innovative images, bold prosodic transitions, the synthesis of a documentary and generalization are the most specific features of Carl Sandburg's poetry prompted by the reality itself - the urban and industrial reality of the America of the 20th century. Sandburg managed to reflect the lights and shadows of the social experience that influenced the life of ordinary Americans of that epoch.

In the blue Susquehanna 
On a Saturday morning

I saw a mounted constabulary go by,

I saw boys playing marbles.

Spring and the hills laughed.

And in places

Along the Appalachian chain,

I saw steel arms handling coal and iron,

And I saw the white-cauliflower faces

Of miner's wives waiting for the men to come home from the day's work.

I made color studies in crimson and violet

Over the dust and domes of culm at sunset.

(C. Sandburg, "Pennsylvania")

In the context of our research, the linguo-cognitive analysis of the lyrical $I$ in the poetic discourse of Carl Sandburg lies in the reconstruction of typical concepts in his conceptual sphere with the help of which the imagery of the lyrical I is formed as well as in the revelation of their key characteristics. In our research, we will focus on the following concepts used in the poetic discourse of Carl Sandburg: LIFE, DEATH, LOVE, MAN, CITY, MORNING and NIGHT.

The conceptual metaphors in the poetic discourse of Carl Sandburg that reveal the concept of LIFE are represented in the following way: LIFE IS AN EVERYDAY ROUTINE-The middle-class passengers witness low life, The car windows frame low life all day in pictures ("Slants at Buffalo, New York"), LIFE AND DEATH ARE JOYS-There was joy on his face when he died as there was joy on his face when he lived ("Jack"), LIFE IS A CONSTANT CHANGE - If I had a million lives to live / and a million deaths to die / in a million humdrum worlds, / I'd like to change my name / and have a new house number to go by / each and every time I died / and started life all over again.

As we can see, Sandburg's attitude to life is rather pessimistic, he often dispraises it, refers to it ironically, sometimes comparing it with death.

Incidentally, the motif of death is one of the main themes in the poetry of Carl Sandburg, therefore the concept of DEATH is widely used in his discourse with the help of which the imagery of the lyrical I is reconstructed. For instance, in his poem "Good Morning, America" the concept DEATH is activated by the following explicata: death, dead, die and implicata so many gone, go west. The universal symbol of death-the skull and crossbones -also belongs to implicata. It is significant that the poetic images which include such explicata and implicata precede more complex poetic effects and, thus, remove the ambiguity in understanding the latter. For example, the phrase The good die young predetermines the interpretation of the following poetic image: When they put you in / that six foot bungalow, that wooden kimono, where one can easily detect the metaphor that defines a coffin which, in its turn, is a metonymic indication of death. The concept of DEATH is actualized in the following poetic image: History is a living horse laughing at a wooden horse, where "a wooden horse" or gallows also represent the metonymy of death.

In the following example, the title of the verse "Death Snips Proud Men" unambiguously activates the concept DEATH. The external verbal level of the poem helps to understand this concept via the following conceptual metaphor: DEATH IS AN ANIMATE CREATURE which receives various explication in different poetic images of the text: Death (...) throws a pair of dice and says: Read'em and weep -DEATH IS A GAMBLER; Death (...) comes with a master-key and lets himself in and says: We'll go now"-DEATH IS A BURGLAR; Death is a nurse mother with big arms: Twon't hurt you at all; it's your time now; you just need a long sleep, child-DEATH IS A NURSE.

Another verse by Carl Sandburg "The Road and the End" as different from the previous examples, does not contain any poetic images objectifying the concept of DEATH in its direct meanings explicitly expressed by nominative units. This concept is reconstructed when reading the final lines of the poem The dust of the traveled road / Shall touch my hands and face the reader comes back to the previous poetic images which objectify the following conceptual metaphor: LIFE IS A ROAD. Based on it, the other conceptual metaphor is comprehended - DEATH IS THE END OF THE ROAD. 
Carl Sandburg's poem "Bringers" does not localize explicata at the verbal level promptly actualizing the concept of DEATH, either: Cover me over / In dusk and dust and dreams. / Cover me over / And leave me alone. / Cover me over, / You tireless, great. / Hear me and cover me, / Bringers of dusk and dust and dreams. It can be assumed that the implicative words dusk, dust, dreams objectify the archetype of DARKNESS which in its turn activates the concept of DEATH. Still, we have to admit that such an assumption of ours will be rather subjective.

The theme of love is also close to Carl Sandburg, though the key concept in his discourse is realized by using the following conceptual metaphors: LOVE IS A PAIN-I have loved the prairie as a man with a heart shot full of pain over love ("Prairie"), LOVE IS A NATURAL BEAUTY_Rivers cut a path on flat lands. / The mountains stand up. / The salt oceans press in / And push on the coast lines. / The sun, the wind, bring rain / And I know what the rainbow writes across the east or west in a half-circle: / A love-letter pledge to come again ("Prairie"), LOVE IS AN ILLUSION-Love is a fool star ("Offering and Rebuff"), LOVE IS UNIVERSE-She had languages and landscapes / on her lips and the end of her tongue, / landscapes of sunny hills and changing fogs, / of houses falling and people within falling ... women / stricken and lost / amid the javelins and chants / of love beyond keeping ("Love Beyond Keeping"), LOVE IS A PROFUSION-My love is a yellow hammer spinning circles in Ohio, Indiana. / My love is a redbird shooting flights in straight lines in Kentucky and Tennessee. / My love is an early robin flaming an ember of copper on her shoulders in March and April. / My love is a graybird living in the eaves of a Michigan house all winter. / Why is my love always a crying thing of wings? ("Haze"), LOVE IS ABOVE ALL-And she formed his name on her tongue and sang / And she sent him word she loved him so much, / So much, and death was nothing; work, art, home, / All was nothing if her love for him was not first / Of all ("Circles of Doors"), LOVE IS ENDLESS—I love, I love, I love, she sang short and quick in / High thin beaten soprano and he knew the meanings, / The high chaser of laughter, the doors on doors / And the looking glasses, the room to room hunt, / The ends opening into new ends always ("Circles of Doors).

The image component of the concept of MAN in the poetic discourse of Carl Sandburg is formed by conceptual metaphors that most fully define the peculiarities of conceptualization of relations between people and the world in which they live: MAN IS MASTER OF HIS LIFE-He sleeps under bridges / with lonely crazy men; he sits in country / jails with bootleggers; he adopts the children / of broken-down burlesque actresses; he has / cried a heart of tears for Windy MacPherson's / father; he pencils wrists of lonely women (C. Sandburg, "Portrait"), MAN IS IMMORTAL - I am here when the cities are gone. / I am here before the cities come. / I nourished the lonely men on horses. / I will keep the laughing men who ride iron. / I am dust of men (C. Sandburg, "Prairie"), They laid hands on him and he was a goner. / They hammered him to pieces and he stood up. / They buried him and he walked out of the grave, by God, / Asking again: Where did that blood come from? (C. Sandburg, "Ossawatomie"), MAN IS GOVENOR OF THE WORLD - I am the people - the mob - the crowd - the mass. / Do you know that all the great work of the world is / done through me? / I am the workingman, the inventor, the maker of the / world's food and clothes. / I am the audience that witnesses history (C. Sandburg, "I am the People, the Mob"), MAN LIVES IN LOVE-I don't care who you are, man: / I know a woman is looking for you and her soul is a corn-tassel kissing a south-west wind. ... I don't care who you are, woman: / I know a man is looking for you / And his soul is a south-west wind kissing a corn-tassel. ... I know sons and daughters looking for you / And they are next year's wheat or the year after hidden in the dark and loam (C. Sandburg, "Haze").

Thus, the metaphoric concept of MAN in the poetic discourse of Carl Sandburg is actualized by verbal images creating different conceptual metaphors on this basis. The main cognitive senses conceptualized via the mentioned above metaphors are as follows: "a man is closely connected with the nature that surrounds him", "a man creates his own life himself", "every man leaves a trace in the history of the mankind, thus, he is reflected in the memory of the following generations", "a man makes the history of the society", and "a man always needs love in his life".

Verbalization of the concept of MAN in the poetic discourse of Carl Sandburg is realized with the help of different explicata: man, woman, child, couple, including the metonymies people, mob, crowd, mass etc. The following significant attributes of the concept of MAN are inherent: an animate creature, a creation of nature, a creator of his own life and the life of the society, the subject and object of love.

Carl Sandburg is known to have been a poetic singer of industrial urbanization. That is why it is no wonder that the concept of CITY occupies a significant place in his poetic discourse. It is worth mentioning that the majority of Carl Sandburg's poems are written from the first person singular or in the form of one-member impersonal sentences. It means that the lyrical I in his discourse reflects the image of the author of a poetic text. In this context, it is interesting to observe the way how Carl Sandburg depicts the city in the conceptual and metaphoric sense. We pay attention to the following conceptual metaphors: A CITY IS A CHAOS-In the city among the walls the overland passenger train is choked and the pistons hiss and the wheels curse ("Prairie"), Outside in the street is the 
murmur and singing of life / in the sun-horses, motors, women trapsing along / in flimsy clothes, play of sun-fire in their blood ("In a Breath"), Take any streetful of people buying clothes and groceries, / cheering a hero or throwing confetti and blowing tin horns ... ("Cool Tombs"), A CITY IS A HOPE-I have seen this city in the night and the moon. ... / In the night and the moon the float of the dome is a dream-whisper, a croon of a hope ("Tangibles"), A CITY IS A NIGHT LIFE - In the night, when the sea-winds take the city in their arms, / And cool the loud streets that kept their dust noon and afternoon; /In the night, when the sea-birds call to the lights of the city, / The lights that cut on the skyline their name of a city; / In the night, when the trains and wagons start from a long way off / For the city where the people ask bread and want letters; / In the night the city lives too-the day is not all. / In the night there are dancers dancing and singers singing, / And the sailors and soldiers look for numbers on doors. / In the night the sea-winds take the city in their arms ("Night Movement-New-York"), A CITY IS A BRILLIANT PERFORMANCE—Let the lights of Broadway spangle and splatter-and the taxis hustle the crowds away when the show is over and the street goes dark ("Crabapple Blossoms"), A CITY IS A CONSTANT MOVEMENT_Dust of the feet / And dust of the wheels, / Wagons and people going, / All day feet and wheels. ... / Voices of dollars / And drops of blood / Voices of broken hearts, / Voices singing, singing ("Clark Street Bridge").

It should be emphasized that when describing urban images Carl Sandburg often uses concepts traditionally belonging to the rural figurative realm as well as images of nature. In our research, such concepts are MORNING and NIGHT.

In Carl Sandburg's understanding, MORNING IS A PLEASANT SMELL_Summer mornings on the docks I walk among bushel peach baskets piled ten feet high. / Summer mornings I smell new wood and the river wind along with peaches. / I listen to the steamboat whistle hong-honging, hong-honging across the town. / And once I saw a teameo straddling a street with a hayrack load of melons ("Potato Blossom Songs and Jigs"), MORNING IS A PALETTE OF COLORS - The bashful mornings hurl gray mist on the stripes of sunrise. / Creep, silver on the field, the frost is welcome. / Run on, yellow balls on the hills, and you tawny pumpkin flowers, chasing your lines of orange ("Tawny"), MORNING IS A DESIRE - Many birds and the beating of wings / Make a flinging reckless hum / In the early morning at the rocks / Above the blue pool / Where the gray shadows swim lazy. / In your blue eyes, O reckless child, / I saw today many little wild wishes, / Eager as the great morning ("Margaret"), MORNING IS A PLEASANT ENTERTAINMENT - In the morning, a Sunday morning, shadows of sea and adumbrants of rock in her eyes ... / horseback in leather boots and leather gauntlets by the sea. ... Yes, riding horseback on hills by the sea ... / sitting at the ivory keys in black velvet, a rope of pearls on white shoulders ("Chords").

The concept of NIGHT in the poetic discourse of Carl Sandburg is reflected in the following conceptual metaphors: NIGHT IS A RECREATION - I know in the night I rest easy in the prairie arms, on the prairie heart ("Prairie"), NIGHT IS AN EMPTINESS - I have asked the night questions / and the night has answered nothing ... / I saw the night / put these whispered nothings across the city dust and stones ("Night's Nothings Again"), NIGHT IS A WOMAN - Does the night forget / as a woman forgets? / and remember as a woman remembers? ("Night's Nothings Again"), NIGHT IS LOVE-Who has loved the night more than I have? / Who has loved the fog moon night last night / more than I have? / Out of the sea that song / can I ever forget it? / Out of the sea those plungers / can I remember anything else? / Out of the midnight morning cry: Hoi-a-loa: / how can I hunt any other songs now? ("Far Rockaway Night till Morning").

\section{Conclusions}

Thus, implementing the linguo-cognitive approach to the analysis of the peculiarities of the expression of the lyrical $I$ in the poetic discourse of Carl Sandburg, we have arrived at the conclusions that metaphors take an active part in the formation of the author's individual pattern of the world. They play an important role in the process of integration of the poet's and the reader's mental and sensual systems. They are also a key element of language categorization, thinking and world outlook.

The originality of the conceptual metaphors in the poetic discourse of Carl Sandburg lies in the fact that they are based on concepts formed in the consciousness of the addressee and the addresser. They embrace a man's ideas about people's qualities and the reality that surrounds them.

It would be fair to say that there are many other concepts depicting the conceptual sphere of Carl Sandburg which are connected with the expression of the lyrical I of the author's image. Unfortunately, the limits of the article do not allow us revealing all of them fully.

Based on the analysis made in our research, it is possible to sum up that Carl Sandburg's lyrical I describes a man of labor, depicts a difficult life of a man in an industrial city, shows the author's appeal in support of a man's fighting for his rights, for peace and freedom. In the poetic discourse of Carl Sandburg, the lyrical I is 
represented by means of an urban figurativeness, a newspaper style of the language, a perfect skill of using blank verse resembling song folklore, a wide use of local expressions and dialectal words, colloquial language and prosaisms.

\section{References}

Aubakir, S. (2019). Features of poetic discourse.

Barrett, L. F., Lindquist, K. A., \& Gendron, M. (2007). Language as context for the perception of emotion. Trends in Cognitive Science, 11, 327-332. https://doi.org/10.1016/j.tics.2007.06.003

Benveniste, E. (1980). Problèmes de linguistique Générale (p. 2).

Briesemeister, B. B., Kuchinke, L., Jacobs, A. M., \& Braun, M. (2014). Emotions in reading: dissociation of happiness and positivity. Cognitive, Affective, \& Behavioral Neuroscience, 15, 287-298. https://doi.org/10.3758/s13415-014-0327-2

Callahan, N. (1987). Carl Sandburg: His Life and Works. University Park: Pennsylvania State UP.

Dixon, P., Bortolussi, M., Twilley, L. C., \& Leung, A. (1993). Literary processing and interpretation: towards empirical foundations. Poetics, 22, 5-33. https://doi.org/10.1016/0304-422X(93)90018-C

Gavins, J., \& Steen, G. (2003). Cognitive Poetics in Practice (p. 188). London-New York: Routledge. https://doi.org/10.4324/9780203417737

Hanauer, D. (1997). Poetic text processing. Journal of Literary Semantics, 26(3), 157-172. https://doi.org/10.1515/jlse.1997.26.3.157

Hoffstaedter, P. (1987). Poetic text processing and its empirical investigation. Poetics, 16, 75-91. https://doi.org/10.1016/0304-422X(87)90037-4

Jones, P. (1980). Carl Sandburg, 1878-1967. Reader's Guide to Fifty American Poets. New York: Barnes \& Noble.

Kneepkens, L. J., \& Zwaan, R. A. (1994). Emotion and cognition in literary understanding. Poetics, 23, 125-138. https://doi.org/10.1016/0304-422X(94)00021-W

Koepsell, K., \& Spoerhase, C. (2008). Neuroscience and the study of literature. Some thoughts on the possibility of transferring knowledge. Journal of Literary Theory, 2(2), 363-374. https://doi.org/10.1515/JLT.2008.024

Luján, A. Á. (2019). Elements for a Cognitive Analysis of Poetic Discourse. Verba Hispanica, 26(1), 213-232. https://doi.org/10.4312/vh.26.1.213-232

Marina, O. (2018). Paradoxicality in Modern English Poetic Discourse: Testing Boundaries of Linguistic Research in the 21st Century. Cognition, Communication, Discourse, 15, 39-50.

Neely, M. E. Jr. (1983). Carl Sandburg. Dictionary of Literary Biograph, 17, 378-382.

Reed, B. (2004). Carl Sandburg's The People, Yes, Thirties Modernism, and the Problem of Bad Political Poetry. Texas Studies in Literature and Language, 46(2), 181-212. https://doi.org/10.1353/tsl.2004.0009

Salwak, D. (1988). Carl Sandburg: A Reference Guide. Boston, G. K. Hall and Co.

Sandburg, C. (2012). Poems. Retrieved from www.poemhunter.com/i/ebooks/pdf/carl_sandburg_2012_3.pdf

Spacey, A. (2019). Analysis of "Fog" by Carl Sandburg. Retrieved from https://owlcation.com/humanities/Analysis-Of-Poem-Fog-by-Carl-Sandburg

Stockwell, P. (2007). Cognitive poetics and literary theory. Journal of Literary Theory, 1, 136-152. https://doi.org/10.1515/JLT.2007.008

Tillmann, B., \& Dowling, W. J. (2007). Memory decreases for prose, but not for poetry. Memory \& Cognition, 35, 628-639. https://doi.org/10.3758/BF03193301

Tsur, R. (1992). What makes sound patterns expressive? The poetic mode of speech perception. Durham, NC: Duke University Press. https://doi.org/10.1215/9780822378365

Ullrich, S., Aryani, A., Kraxenberger, M., Jacobs, A. M., \& Conrad, M. (2015). Where are emotions in a poem? Sub-lexical iconicity, lexical surface features and dynamic inter-lexical shifts. Front. Psychol.

Van Dijk, T. A. (1979). Advice on theoretical poetics. Poetics, 8, 569-608 https://doi.org/10.1016/0304-422X(79)90034-2 
Villarreal, E. (2006). Recovering Carl Sandburg: Politics, Prose, and Poetry After 1920 (p. 189). A dissertation. The University of Texas-Pan American.

Walsh, G. (2010). Schema Poetics and Crossover Fiction. In L. Marine \& S. Peter (Eds.), Contemporary Stylistics. London: Continuum.

Wassiliwizky, E., Koelsch, S., Wagner, V., Jacobsen, T., \& Menninghaus, W. (2017). The emotional power of poetry: neural circuitry, psychophysiology and compositional principles. Social Cognitive and Affective Neuroscience, 12(8), 1229-1240. https://doi.org/10.1093/scan/nsx069

Yannella, P. R. (1996). The Other Carl Sandburg. Jackson: UP of Mississippi.

\section{Copyrights}

Copyright for this article is retained by the author, with first publication rights granted to the journal.

This is an open-access article distributed under the terms and conditions of the Creative Commons Attribution license (http://creativecommons.org/licenses/by/4.0/). 